\title{
アルミニウム電解着色皮膜の再アノード酸化による 微細構造の変化と着色制御
}

(1983 年 6 月 7 日受 理)

和田 健二*・松井良夫・関川喜三・下平高次郎

アルミニウムの電解着色皮膜の機能化と強化を目的として, 電解着色皮膜への再アノード酸化の導入 を検討した。そしてホウ酸アンモニウム水溶液中での再アノード酸化時の印加電圧と電解時間が皮膜の 色におよぼす影響を調べた結果, 硫酸ニッケルと硫酸スズ(II)によるどちらの着色皮膜にも淡色化現象 が認められ, 着色制御できることが明らかとなった。さらにこれらの着色皮膜の再アノード酸化前後に おける微細構造の变化を電子顕微鏡で観察するとともに, 再アノード酸化時の電解時間の経過にともな ら電流密度の変化から, 析出物とバリヤー層に変化が生じていることを認めた。すなわち再アノード酸 化時に起こる淡色化は, 硫酸ニッケルによる着色皮膜では析出物のポアーからの離脱に起因し, 硫酸ス ズ（II）による着色皮膜では析出物の上部での不動態層の生成に起因する。析出物とバリャー層との密着 性は析出物の種類やポアーによって異なるが，この原因はおもにアノード酸化時に生成したバリヤー層 の厚さのバラッキと析出物中の微細粒子の有無に関連することを推察した。また，着色皮膜がバリヤー 層の增厚化や析出物の不動態化によって強化されることを報告した。

\section{1 緒 言}

アルミニウムのアノード酸化で得られた多孔質のアルミナ皮膜 （以下皮膜と略記する）を，硫酸ニッケルや硫酸スズ(II)のよう な金属塩を主成分とした水溶液中で交流電解すると，ポアー中に 金属が析出することはすでによく知られている112)。着色が目的 の場合には，とくに電解着色法と呼ばれ技術がほぼ確立されてい る。しかし最近ではこうした単なる着色皮膜としての用途にとど まらず，皮膜中に金属や様々な化合物を種々の方法で導入するこ とによって，皮膜の新しい機能を引き出そうとする多くの試みが なされているる 。しかしながら現在実用化されたものはまだ少 なく，多くは研究途上にあって今後の検討が期待されている。実 用化の遅れているおるな原因は，新たな機能を付加したにもかか わらず性能面や耐久性が十分でないことと、コスト面における問 題のようである。

本研究は以上のような事柄を背景として, 皮膜のおもに触媒お よびェレクトロニクス材料としての新たな機能を引き出すことと

科学技術庁 無機材質研究所, 305 茨城紧新治郡桜村並木

1）浅田太平，金属表面技術，21，495(1970).

2) T.Sato, S.Sakai, Trans. Inst. Metal Finish., 57, 43 (1979).

3) S. Kawai, R. Ueda, J. Electrochem. Soc., 122, 32 (1975).

4）水木一成，馬場宣良，吉野隆子，金属表面技術，31，75 (1980).

5）山本裕三，馬場宣良，田島 栄，日化，1982，1129.

6) I. Mita, M. Yamada, Chem. Lett., 1981, 123.

7) N. Baba, T. Yoshino, J. Appl. Electrochem., 12, 607 (1982).
強化することを目的として，電解着色皮膜への再アノード酸化を 行なった。一般にアルミニウムの電解着色皮膜は, 着色処理後再 アノード酸化を行ならとポアー中に沈着していた析出物がアノー ド溶解して色抜けが起こるといわれている8)。したがって今日ま で, 電解着色皮膜に電気化学的な処理を行なら試みはほとんどな されていない。

ところが著者らのこれまでの研究によって，ポアー中の析出物 が用いた金属塩の種類によって色や形態に差があるだけでなく， バリヤー層の厚さや析出物とバリヤー層との密着性にも影響をお よぼすことが明らかとなってきだの。とくに皮膜を生成してから 電解着色処理を行ならをでの間に, 中間処理を行なってポアー中 の孔壁とバリヤー層を化学的にいったん薄くした場合には，析出 物とバリヤー層との界面に「pore-filling」現象が起こって, こ れらの間の密着性を強化することが判明しだ9。

本研究はこのような結果を踏まえて, 金属塩の種類や中間処理 の有無によっては, 電解着色皮膜への電気化学的な処理が可能で あることを推察した。そして実際に電解着色皮膜に対して再ア， 一ド酸化を行なった結果, 用いた金属塩の種類によっては析出物 が見かけ上アノード溶解せずにバリヤ一層から㕍脱するものと， 析出物がバリヤー層から離脱せずに不動態化するものとに分類さ れ，電気化学的な処理が可能であることが明らかとなった。しか もこのさい, 電解着色皮膜の色が再アノード酸化時の印加電圧と 電解時間によって淡色化し，着色制御できることが判明した。し

8）野崎 弘，本多健一，半谷な括子，小林光一，生産研究 (東京大学)，23，1(1971).

9）和田健二，松井良夫，関川喜三，下平高次郎，金属表面技 術, 33, 238(1982). 
たがって本研究では, 主として再アノード酸化前後におけるポア 一中の析出物の変化やバリヤー層の増厚化および析出物とバリヤ 一層との密着性に注目し, 電解着色皮膜の微細構造と着色制御と の関係を追求して新たな知見を得たので報告する。

\section{2 実験}

\section{1 アノート酸化と中間処理}

アルミニウムの材料は純度 $99.3 \%$ 以上の厚さ $100 \mu \mathrm{m}$ のア ルミニウムハクを用いた。前処理はアルミニウムハクの表面をト リクロロエチレンを含ました脱脂綿でよく拭く方法で行なった。

アノード酸化は $1 \mathrm{~mol} \cdot \mathrm{dm}^{-3}$ 硫酸 $\left(20^{\circ} \mathrm{C}\right.$, 直流 $\left.15 \mathrm{~V}\right)$ と 0.2 $\mathrm{mol} \cdot \mathrm{dm}^{-3}$ リン酸 $\left(21^{\circ} \mathrm{C}\right.$, 直流 $\left.21 \mathrm{~V}\right)$ の水溶液中で定電圧法で行 ない，アルミニウムの表面に非晶質のアルミニウム酸化物からな る皮膜を生成させた（以下硫酸およびリン酸の水溶液中で生成し た皮膜を硫酸皮膜，リン酸皮膜とそれぞれ略記する)。電解時間 は必要とする膜厚に応じて変えたが，原則として硫酸水溶液中で は 15〜30 分とし, リン酸水溶液中では 40〜75 分とした。

中間処理は皮膜中のバリヤー層と孔壁を化学的に溶解して薄く する目的で行なった。この方法はアノード酸化によって得られた 皮膜を, $40^{\circ} \mathrm{C}$ に加温した $1 \mathrm{~mol} \cdot \mathrm{dm}^{-3}$ 硫酸水溶液中に浸漬して 行なった ${ }^{10)}$ 。

\section{2 電解着色}

電解着色処理は，上記アノード酸化によって得られた無色透明 の硫酸皮膜とリン酸皮膜を $0.2 \mathrm{~mol} \cdot \mathrm{dm}^{-3}$ 硫酸ニッケル水溶液 に $0.5 \mathrm{~mol} \cdot \mathrm{dm}^{-3}$ ホウ酸を加えた水溶液 (以下硫酸ニッケル水溶 液と略記する), または $0.1 \mathrm{~mol} \cdot \mathrm{dm}^{-3}$ 硫酸スズ(II)水溶液に $0.003 \mathrm{~mol} \cdot \mathrm{dm}^{-3}$ クレゾールスルホン酸を添加した水溶液（以下 硫酸スズ水溶液と略記する) 中に浸漬して, 交流 $15 \mathrm{~V}$ を印加し て行なった。これによって硫酸皮膜は褐色系に呈色し，リン酸皮 膜は原色とこれらの中間色を含む鮮やかな色を呈し多色化し た ${ }^{11)}$ 。

硫酸皮膜に対する電解着色の処理時間は, 硫酸ニッケル水溶液 中で 5〜30 分, 硫酸スズ水溶液中で $3 \sim 10$ 分とした。リン酸皮 膜の場合には, 皮膜を硫酸ニッケル水溶液中で 20 秒間隔で段階 的に引き上げ, 最高 200 秒まで行なった。硫酸スズ水溶液中で は，同様に皮膜を 5 秒間隔で引き上げ，最高 50 秒まで行なっ た。

\section{3 再アノード酸化}

再アノード酸化は, 電解着色処理後 $0.05 \mathrm{~mol} \cdot \mathrm{dm}^{-3}$ ホウ酸了 ンモニウム水溶液（pH 6.6）中で定電圧法で行なった。最大印 加電圧は直流 $150 \mathrm{~V}$ とした。電解時間はとくに規定しないかぎ り原則として 30 秒とした。再アノード酸化時の電流密度の変化 は, 理研電子(株)製の SP-H 3 P 型高速精密記録計を用いて测 定した。

\section{4 微細構造の観察}

電子顕微鏡用試料の作成は，始めに再アノード酸化処理前後の 電解着色皮膜をエポキシ樹脂中に埋め込んだのち, $60^{\circ} \mathrm{C}$ の乾燥 器中で 48 㭙聞以上加髙し硬化させる。ついでこの皮膜を包埋し た試料をステンレススチール製ナイフとガラス製ナイフを使って

10) 承山政一，田村和利，電化，36，34(1968).

11) K. Wada, T. Hatano, K. Uchida, J. Appl. Electrochem., 9, 446(1979).

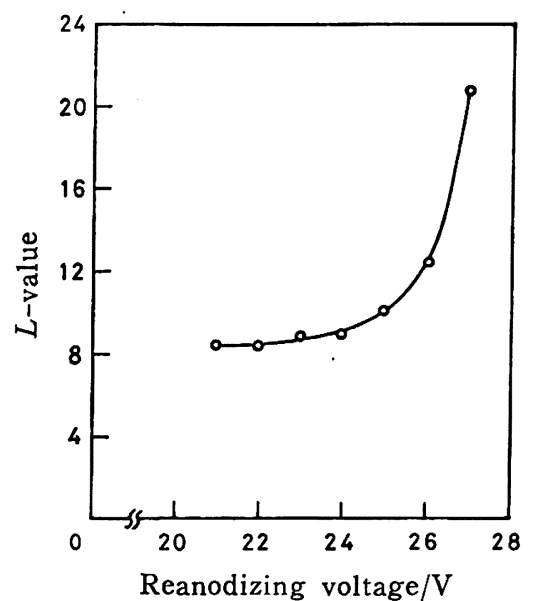

Fig. 1 Relationship between exponential value of brightness of the colored film and the reanodizing voltage

Anodizing : $1 \mathrm{~mol} \cdot \mathrm{dm}^{-3}$ Sulfuric acid (15 V), $t=30$ $\min$

Coloring : $0.2 \mathrm{~mol} \cdot \mathrm{dm}^{-3}$ Nickel sulfate, $t=5 \mathrm{~min}$ Reanodizing : $0.05 \mathrm{~mol} \cdot \mathrm{dm}^{-3}$ Ammonium borate, $t=$ $30 \mathrm{~s}$

トリミング後, DuPont 社製ダイヤモンドナイフを装着した LKB 社製 V 型 2088 超ミクロトームで厚さ約 $40 \mathrm{~nm}$ の連続切片を 切り出した。そして最後に銅製のシートメッシュですくったもの を試料とした ${ }^{12)}$ 。

電子顕晸鏡観察は，(株)日立製作所製の H-500 透過型電子顕 微鏡 $(100 \mathrm{kV})$ と $\mathrm{H}-1250$ 超高圧高分解能電子顕微鏡 $(1000 \mathrm{kV})$ を使用して行なった。

\section{5 色の 測 定}

電解着色皮膜の再アノード酸化前後の色の変化は，スガ試験機 (株)製の SM-2 型カラーュンピューターにより $L$ 值 (明度指 数値)を测定した。

\section{3 結 果}

\section{1 着色制御之微細構造の变化}

3.1 .1 硫酸ニッケルによる電解着色皮膜の再アノード酸化： 硫酸ニッケル水溶液中で電解着色処理して得られた褐色の硫酸皮 膜は, 再アノード酸化時の印加電圧の増加とともに表面から酸素 ガス ${ }^{8)}$ 発生して色が淡色化する。このようすを示したのが図 1 である。図 1 は印加電圧の增加にともなう着色硫酸皮膜の淡色化 の傾向を $L$ 値との関係で表わしている。印加電圧が $22 \mathrm{~V}$ 付近 までは，前の電解着色時の交流の印加電圧が $15 \mathrm{~V}$ でピーク電圧 としては $21 \mathrm{~V}$ かかっていることになり，したがって電流はほと んど流れない。それゆえこの間は皮膜の微細構造に变化が起こら ず，皮膜の色は変化しない。ところが印加電圧が $23 \mathrm{~V}$ 付近から 徐々に電流が流れ始め, $25 \mathrm{~V}$ 以上では皮膜の表面から酸素がス の発生をともなって電流が急に流れ出す。このような状態になる と着色皮膜には淡色化が始まり，しかも電解時間の経過とともに 次第に淡色化はいちじるしくなる。

そして最終的には，着色皮膜をむとの硫酸皮膜に特有な無色透 12）赤䏱 宏，電子顕微鏡，12，21(1977). 


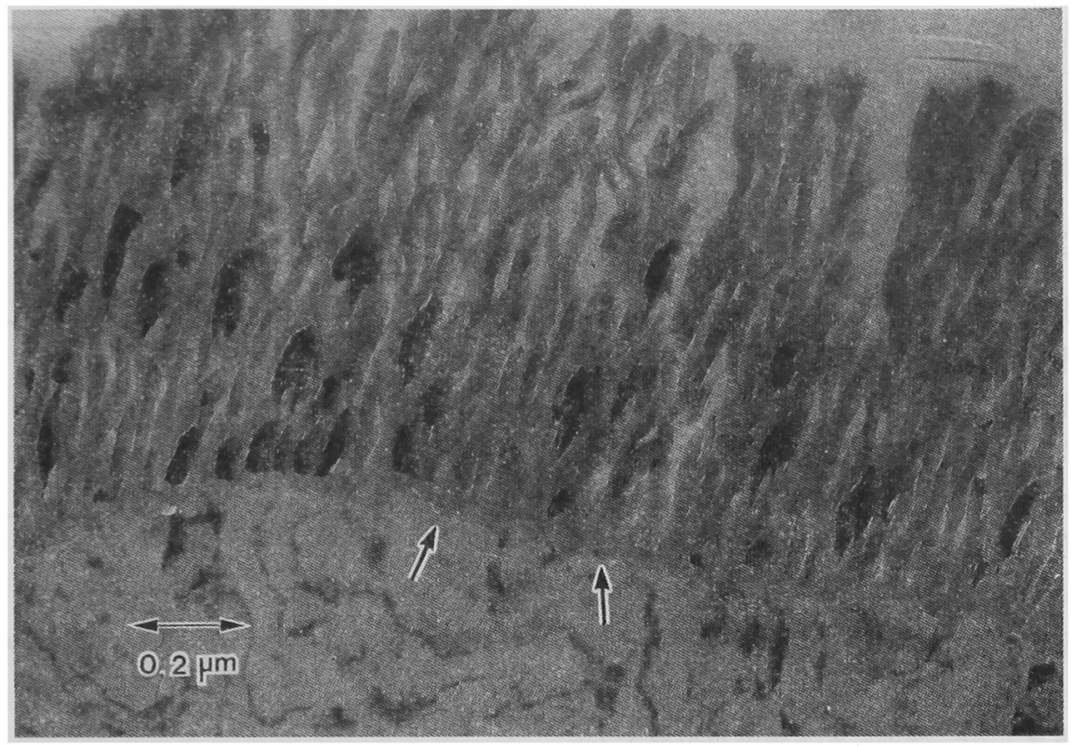

Fig. 2 Transmission electron micrograph showing leave of the nickel deposits from the barrier layer by reanodizing of the colored film

Anodizing : $0.2 \mathrm{~mol} \cdot \mathrm{dm}^{-3}$ Phosphoric acid (21 V), $t=70 \mathrm{~min}$

Coloring : $0.2 \mathrm{~mol} \cdot \mathrm{dm}^{-3}$ Nickel sulfate, $t=3 \mathrm{~min}$

Reanodizing : $0.05 \mathrm{~mol} \cdot \mathrm{dm}^{-3}$ Ammonium borate $(25 \mathrm{~V}), t=120 \mathrm{~s}$

明まですどすことができる。硫酸ニッケル水溶液中で多色を呈し たリン酸皮膜においても同様の淡色化が認められるが，硫酸皮膜 の場合と異なる点は原色を呈した皮膜が徐々に鮮やかさを失って いったん褐色に変化することである。その後は硫酸皮膜と同様の 傾向を示す。

着色皮膜が再アノード酸化時に淡色化する原因を調べるため に，皮膜の縦断面を電子顕微鏡で観察した結果が図 2 である。図 2 は硫酸ニッケル水溶液中で 180 秒電解着色処理して得られた 黒色に近いリン酸皮膜を, 直流 $25 \mathrm{~V}$ で 120 秒間再アノード酸化 して淡色化した皮膜の微細構造を示している。ポアー中の析出物 は, 再アノード酸化を行なら前はポアーの底のバリヤー層上に沈 着している。しかし再アノード酸化後には, 図に見られるように 析出物がハリヤー層からランダムに離脱していくようすが示され ている。このポフー中の析出物は微細な粒子で形成されていて， その粒子の組成は金属状のニッケルを主成分とすることが判明し ているッ(以下硫酸ニッケル水溶液から得られた析出物は $\mathrm{Ni}$ 析出 物と略記する)。

図2では Ni 析出物がポアーから完全に離脱したところや，離 脱が進行中のところ，そしてまた Ni 析出物がバリヤー層に沈着 しているところも観察される。ポアーから離脱途中の Ni 析出物 の下側には, 尖った形状が認められる。この結果は, Ni 析出物 がパリヤー層から簡単に離脱したものでないことを暗示してい る。

ハリリー層の厚さについては， $\mathrm{Ni}$ 析出物がバリヤー層に付い ているところと，すでにハリヤー層から離脱したところでは差が 見られる。前者の場合にはハシリヤー層の厚さは $26 \sim 32 \mathrm{~nm}$ 程度 であるのに対し，後者では $32 \sim 39 \mathrm{~nm}$ と明らかに增厚化してい る（図に矢印で示した）。

3.1 .2 硫酸スス(II)による電解着色皮膜の再アノート酸化： 硫酸スズ水溶液中で電解着色処理した褐色の硫酸皮膜は, 再了

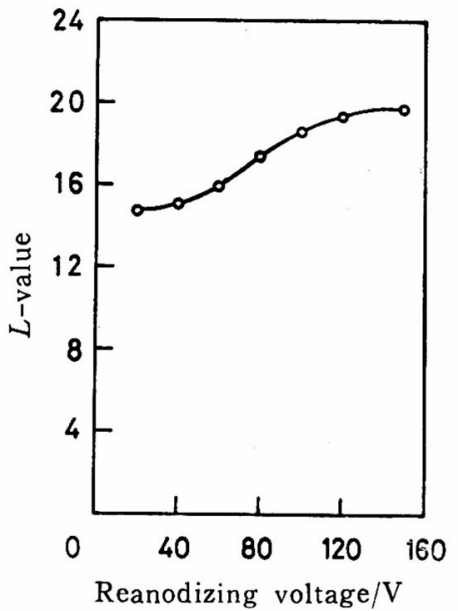

Fig. 3 Relationship between exponential value of brightness of the colored film and the reanodizing voltage

Anodizing : $1 \mathrm{~mol} \cdot \mathrm{dm}^{-3}$ Sulfuric acid $(15 \mathrm{~V}), \quad t=30$ $\min$

Coloring : $0.1 \mathrm{~mol} \cdot \mathrm{dm}^{-3}$ Tin sulfate, $t=2 \mathrm{~min}$

Reanodizing : $0.05 \mathrm{~mol} \cdot \mathrm{dm}^{-3}$ Ammonium borate, $t=$ $30 \mathrm{~s}$

ノード酸化時の印加電圧の上昇とともに図 3 に示したような淡色 化の傾向を示す。硫酸ニッヶルによる着色皮膜では, 淡色化の起 こり始めるさいの印加電圧が $23 \mathrm{~V}$ 付近であるのに対し, 硫酸ス ズ水溶液中で呈色させた皮膜の場合には, 印加電圧が $20 \sim 30 \mathrm{~V}$ の範囲内では皮膜の色にはほとんど変化が見られない。しかし印 加電圧が $40 \mathrm{~V}$ を過ぎる頃からはげしい酸素がスの発生をともな って，皮膜には淡色化の傾向が現われ始める。50 V のときには， 肉眼でも明らかに着色皮膜の淡色化が観察される。印加電生が約 


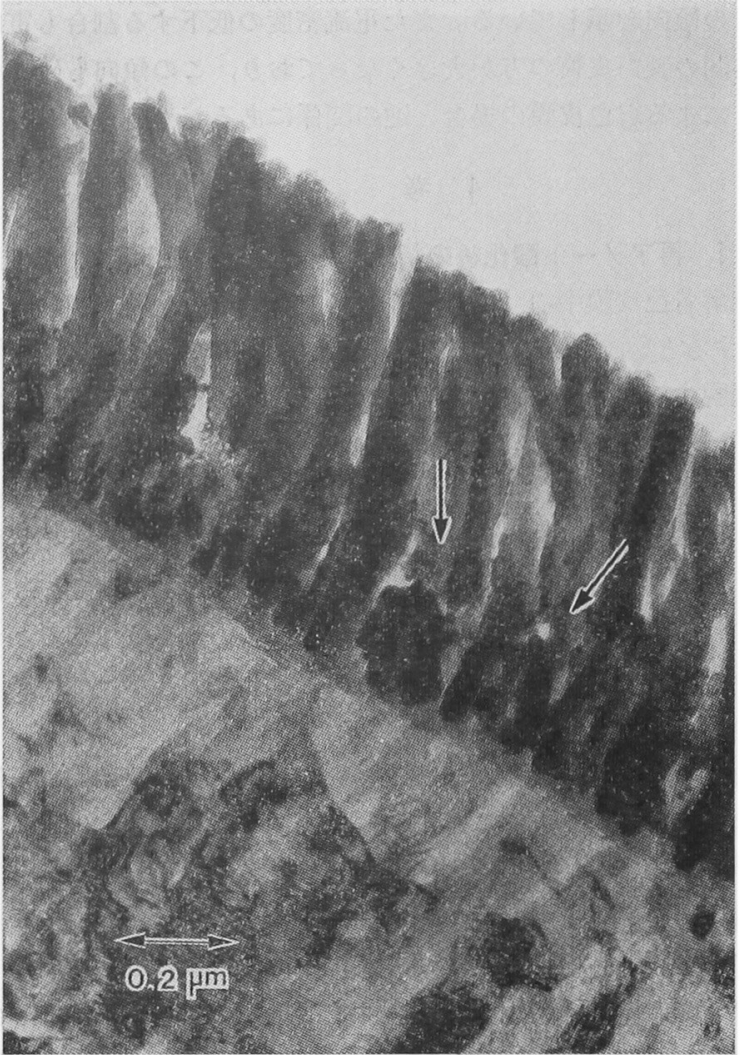

Fig. 4 Transmission electron micrograph showing variation of the microstructure of the top in the tin deposits by reanodizing of the colored film

Anodizing : $0.2 \mathrm{~mol} \cdot \mathrm{dm}^{-3}$ Phosphoric acid (21 V), $t=60 \mathrm{~min}$

Coloring : $0.1 \mathrm{~mol} \cdot \mathrm{dm}^{-3}$ Tin sulfate, $t=20 \mathrm{~s}$

Reanodizing : $0.05 \mathrm{~mol} \cdot \mathrm{dm}^{-3}$ Ammonium borate (100

V), $t=30 \mathrm{~min}$

60〜 $100 \mathrm{~V}$ の範用内では, 図 3 に示されているように皮膜の色は 印加電圧に比例して着色制御でさる。しかし約 $100 \mathrm{~V}$ 以上の電 圧では淡色化の傾向は低下し，皮膜の色は硫酸ニッケルによる着 色皮膜のときのように無色透明までもどらず，相違が認められ る。

図 4 はリン酸皮膜を硫酸スズ水溶液中で 20 秒間電解着色処理 後, 直流 $100 \mathrm{~V}$ で再アノード酸化したときのポアー中の析出物 とバリヤー層の微細構造を示している。ポアー中の析出物中に は, $\mathrm{Ni}$ 析出物中に見られるような微細粒子は認められず9)13)14), 電子線回折により析出物の組成を調べた結果, 金属スズを示す回 折斑点が得られた（以下硫酸スズ水溶液から得られた析出物は Sn 析出物之略記する)。ポアー中の Sn 析出物は再アノード酸 化洔にはげしい酸素ガスの発生をともならにもかかわらず，図 4 に見られるようにバリヤー層から離脱することもなく，バリヤー 層との密着性がすぐれていることが示唆される。

バリヤー層には変化が認められないかわりに, Sn 析出物の上 部に微細構造の変化が認められ，よく観察すると微細化が起こっ

13) Y. Hirayama, S. Yamaoka, Y. Oka, K. Yoshida, Proceedings of 10 th World Congress on Metal Finishing, p. 271(1980)

14) J.Patrie, G. Colombier, Proceedings of 10 th World Congress on Metal Finishing, p.292(1980).

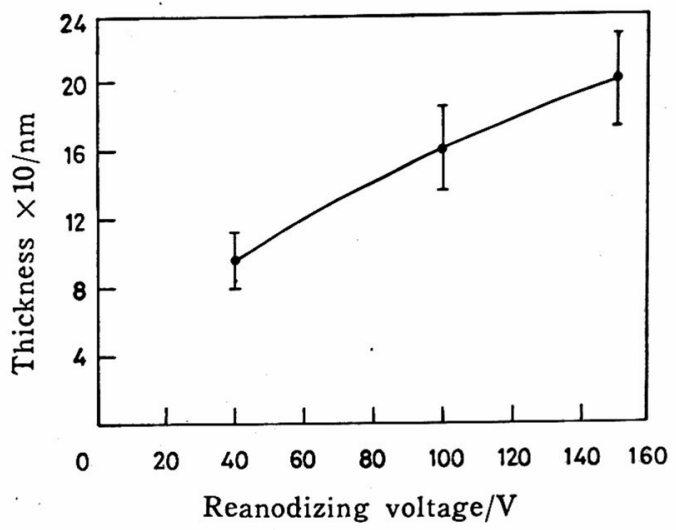

Fig. 5 Variation of the thickness of the transformed layer of the top in the deposits with the reanodizing voltage

Anodizing : $0.2 \mathrm{~mol} \cdot \mathrm{dm}^{-3}$ Phosphoric acid (21 V), $t=60 \mathrm{~min}$

Coloring : $0.1 \mathrm{~mol} \cdot \mathrm{dm}^{-3}$ Tin sulfate, $t=20 \mathrm{~s}$

Reanodizing : $0.05 \mathrm{~mol} \cdot \mathrm{dm}^{-3}$ Ammonium borate, $t=$ $30 \mathrm{~s}$

ているよらである（図に矢印で示した)。この微細化した層の厚 さは, 再アノード酸化時の印加電圧の上昇とともに図 5 に示した ような曲線を描いて厚くなる。印加電圧が $20 〜 30 \mathrm{~V}$ の範囲内 では, Sn 析出物の上部に変化はほとんど認められないが, $40 \mathrm{~V}$ では $96 \mathrm{~nm}$ 程度の厚さの微細化が起こり，100 V では約 $160 \mathrm{~nm}$ の厚さとなる。すなわち Sn 析出物による着色皮膜は, 再アノー ド酸化時のこの微細化した層の厚さに相当する分たけ着色制御で きるものと思われる。

バリヤー層の厚さは再アノード酸化時の印加電圧によって変化 しないたけけでなく，再アノード酸化前後にも差は認められない。 すなわち, 最初のアノード酸化時に得られたりン酸皮膜のバリヤ 一層の厚さはほぼ 21 29 nm であるが，20 秒の電解着色処理に よって 25〜36 nm と増厚化する。しかしその後の再アノード酸 化では印加電圧が $40 \mathrm{~V}$ のとき約 $26 \sim 38 \mathrm{~nm}$ であり, $100 \mathrm{~V}$ で も約 $26.5 \sim 38 \mathrm{~nm}$ と電解着色処理後のパリヤー層の厚さとほと んど差がない。

\section{2 再アノード酸化時の電流密度-時間特性}

図 6 に示した 2 本の電流密度-時間曲線（以下 $j-t$ 曲線之略記 する）は, 硫酸ニッケル水溶液中で 5 分および 10 分電解着色処 理した皮膜を，それぞれ再アノード酸化（印加電圧 $24.5 \mathrm{~V}$ ) し たさいの電解時間の経過にともなら電流密度の变化を比較したも のである。電解開始直後の電流密度はそれぞれ $6.3 \mathrm{~mA} \cdot \mathrm{cm}^{-2}$ と $5.5 \mathrm{~mA} \cdot \mathrm{cm}^{-2}$ であり, 電解時間の長い皮膜の方が電流密度は低 くなっている。このことから $\mathrm{Ni}$ 析出物が成長するほど電気抵抗 が增加することがわかる。その後 $j-t$ 曲線はいずれも電解時間の 経過とともに電流密度が低下するが，電解時間が 5 分のときの曲 線には電流密度が徐々に低下寸る領域と急速に低下する領域が存 在している。これに対して電解時間が 10 分のときの曲線には, 電流密度が急速に低下する領域は認められない。

図 7 に示した 2 本の $j-t$ 曲線は，硫酸スズ水溶液中で 3 分およ び 5 分電解着色処理した皮膜を，直流 $100 \mathrm{~V}$ でそれぞれ再ア， 一ド酸化したさいの電解時間に対する電流密度の变化を示してい る。 $j-t$ 曲線に見られるように再アノード酸化開始直後の電流密 


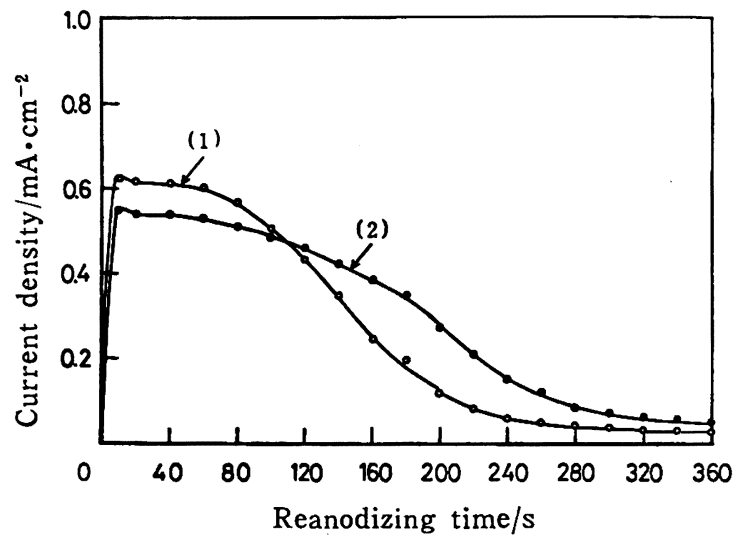

Fig. 6 Variation of the current density with the reanodizing time of the films colored by the nickel deposits

Anodizing : $1 \mathrm{~mol} \cdot \mathrm{dm}^{-3}$ Sulfuric acid (15 V), $t=30$ $\min$

Coloring : $0.2 \mathrm{~mol} \cdot \mathrm{dm}^{-3}$ Nickel sulfate

Time $(\mathrm{min})$

$0: 5, \bigcirc: 10$

Reanodizing : $0.05 \mathrm{~mol} \cdot \mathrm{dm}^{-3}$ Ammonium borate $(24.5$ V)

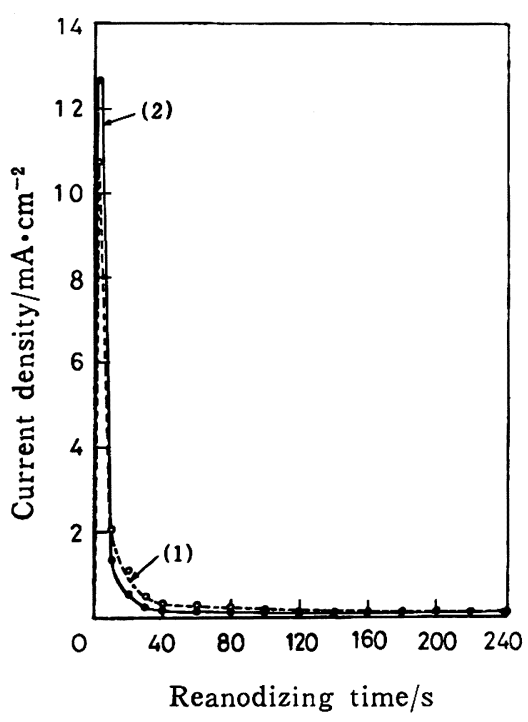

Fig. 7 Variation of the current density with the reanodizing time of the films colored by the tin deposits

Anodizing : $1 \mathrm{~mol} \cdot \mathrm{dm}^{-3}$ Sulfuric acid (15 V), $t=30$ $\min$

Coloring : $0.1 \mathrm{~mol} \cdot \mathrm{dm}^{-3}$ Tin sulfate

Time $(\mathrm{min})$

$0: 3, \bigcirc: 5$

Reanodizing : $0.05 \mathrm{~mol} \cdot \mathrm{dm}^{-3}$ Ammonium borate (100 V)

度はいずれる $100 \mathrm{~mA} \cdot \mathrm{cm}^{-2}$ 以上と高く, 硫酸ニッケルによる着 色皮膜の場合の $6.3 \mathrm{~mA} \cdot \mathrm{cm}^{-2}$ と $5.5 \mathrm{~mA} \cdot \mathrm{cm}^{-2}$ とくらべると きわめて大きな值を示している。しかしこの電解開始直後の大き な電流密度は，その後急激に低下し約 40 秒後には電流はほとん ど流れなくなる。

電解開始直後の電流密度は電解着色時間の長い皮膜の方が大き な値を示しており, 硫酸ニッケルによる着色皮膜の $j-t$ 曲線とは
反対の傾向を示している。また電流密度の低下する割合も電解着 色時間の長い皮膜の方が大きくなっており，この傾向も硫酸ニッ ケルによる着色皮膜の場合と逆の関係にある。

\section{4 考察}

\section{1 再アノード酸化後の析出物とバリヤー屏の变化}

電解着色皮膜中の $\mathrm{Ni}$ 析出物は再アノード酸化時にアノード溶 解 ${ }^{8}$ 寸るといらよりはむしろ, バリヤー層からランダムかつ徐 々 に離脱する。この結果は $\mathrm{Ni}$ 析出物とバリヤー層との密着性が, ポアーによって異なることを示している。 $\mathrm{Ni}$ 析出物とバリヤー 層との密着性が異なる理由は, 電解着色時のバリヤー層の修復と 増厚化にともなって生成する $\mathrm{Ni}$ 析出物とバリヤー層との界面の コロイド状アルミニウム化合物 ${ }^{9)}$ (アルミニウムの水酸化物と推 定される）と析出物との密着性に起因しているようである。つき つめれば, 最初のアノード酸化時に生成したバリヤー層の厚さの 相違に原因すると考えられる。

一般に皮膜中のバリヤー層の厚さは，皮膜生成時の印加電圧に ほぼ比例して厚くなることが知られているが15) 18), 正規分布に

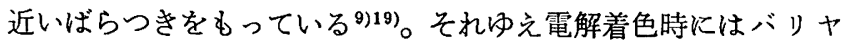
一層の薄いところほど優先的に修復され，しかもホウ酸によるバ リヤー型皮膜への改質を受けて強化される。このとき析出物とバ リヤー層との界面に生成するコロイド状のアルミニウム化合物 （図に矢印で示した）の大きさは，図 8 から約 $5 \sim 7 \mathrm{~nm}$ と測定さ れた。図 8 は 5 分間アノード酸化して得られた硫酸皮膜を,さら に 30 分間中間処理後硫酸ニッケル水溶液中で電解着色処理した 皮膜の微細構造を示している。

図 2 に見られるポアーから離脱中の $\mathrm{Ni}$ 析出物の下側が尖って いる原因は，つぎのように推察される。Ni 析出物とバリヤー層 との密着性が十分でないポアーでは，再アノード酸化時に発生す る酸素ガスによって，析出物はそのままの形でバリヤー層から容 易に離脱する。ところが $\mathrm{Ni}$ 析出物とバリヤー層との密着性が比 較的よいポアーでは, 析出物がはげしい酸素がスの発生によって 途中から強引に引き剝がされて離脱するものと思われる。したが って酸素ガスの発生する場所は, 溶液と接した析出物の頂点面だ けでなく，析出物と孔壁部との界面でも起こっていることが考え られる。また Ni 析出物とバリヤー層との密着性がきわめて悪い ところでは,これらの界面でのガス発生による剥離も予想される。

$\mathrm{Ni}$ 析出物がポフーの底に密着している部分のバリヤー層の厚 さは, 図 2 では約 26〜32 nm (最初のアノード酸化時に生成した バリヤー層の厚さは約 $29 \mathrm{~nm}$ 程度である) 程度であるのに対し, 析出物が離脱したのちのバリヤー層の厚さは約 $32 \sim 39 \mathrm{~nm}$ とな り厚く強化されている。

以上のような結果に対して, 皮膜中の Sn 析出物は再アノード 酸化時にきわめてはゲしい酸素がスの発生をともならにもかかわ らず,バリヤー層から離脱しない。しかも, $\mathrm{Ni}$ 析出物の再アノー

15) F. Keller, M.S. Hunter, D. L. Robinson, J. Electrochem. Soc., 100, 411(1953).

16) H. Akahori, J. Electronmicroscopy, 10, 175(1961).

17) G. C. Wood, J. P. O'Sulliivan, B. Vaszko, J. Electrochem. Soc., 115, 618(1968).

18）永山政一，高橋英明，甲田満，金属表面技術， $30 ４ 38$ (1979).

19) T. Sato, Advanced Metal Finishing Technology in Japan-1980, TECHNOCRAT (1980) p. 79. 


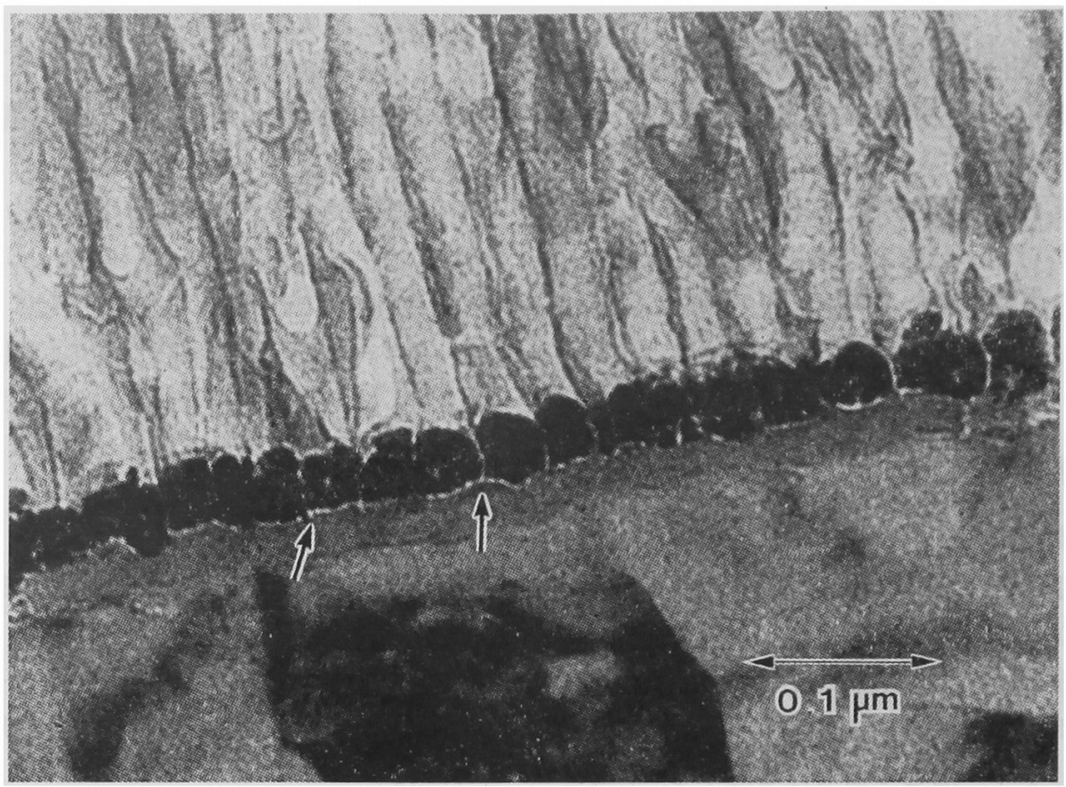

Fig. 8 Transmission electron micrograph showing the size of colloidlike aluminum compounds between the nickel deposits and the barrier layer

Anodizing : $1 \mathrm{~mol} \cdot \mathrm{dm}^{-3}$ Sulfuric acid $(15 \mathrm{~V}), t=5 \mathrm{~min}$

Dissolution : $1 \mathrm{~mol} \cdot \mathrm{dm}^{-3}$ Sulfuric acid $\left(40^{\circ} \mathrm{C}\right), t=30 \mathrm{~min}$

Coloring : $0.2 \mathrm{~mol} \cdot \mathrm{dm}^{-3}$ Nickel sulfate, $t=40 \mathrm{~s}$

ド酸化時の印加電圧がせいぜい直流 $25 \mathrm{~V}$ 前後であるのに対し て，この場合には直流 $100 \mathrm{~V}$ が印加されているにもかかわらず バリヤー層の厚さは $26.5 \sim 38 \mathrm{~nm}$ であって, 再アノード酸化前 にくらべてほとんど変化していない。このことは仮に再アノード 酸化時の電圧がバリヤー層だけにかかったとすると，バリヤー層 の厚さは 1〜1.4 nm/V の関係 ${ }^{15) ~ 18) に あ る た め ~} 100 \sim 140 \mathrm{~nm}$ の 籁囲内にあるはずである。ところが実測值は上記結果に示したと おり,この仮定とまったく異なった值を示している。つまり再ア ノード酸化時の電圧はバリヤー層にかかったのではなく、図 4 お よび図 5 に認められるように Sn 析出物の表面層にかかったもの と推定される。すなわち, 硫酸スズ(II)による電解着色皮膜にお いては, 再アノード酸化時に Sn 析出物のアノード酸化が起こっ ているよらである。

$4.2 \boldsymbol{j}-\boldsymbol{t}$ 曲線による析出物とバリヤー層との密着性および析 出物の状態

図 6,7 に示した再アノード酸化時の $j-t$ 曲線からは, 析出物 とバリヤー層との密着性や析出物とバリヤー層に起こる電気化学 的な変化を推察することがでさる。すなわち図6の電解着色時間 が 5 分の Ni 析出皮膜の $j-t$ 曲線( 1 )には, 再アノード酸化開 始時から約 70 秒経過後まで電流密度のわずかな低下が認められ る。この電流密度の低下は, $\mathrm{Ni}$ 析出物のアノード酸化や析出物と バリヤー層との界面に生成するアルミニウムの化合物に起因した 電気抵抗の増加によるものと考学られる。この期間は， Ni 析出 物が孔壁部とバリヤー層との界面での酸素ガスの発生によって, バリヤー層から離脱するまでの準備期間である。つづいて生じる 80 秒付近から 200 秒付近までの電流密度の急激な低下は, Ni 析 出物がバリヤー層から離脱を開始してからほぼ終了するまでに起 こる, バリヤー層の増厚化に起因するよらである。

最終的に析出物がポアーから完全に抜けてバリヤー層を厚く強
化し，電流がほとんど流れなくなる時間は電解開始後約 260 秒 である。この時点における着色皮膜の色は, 着色処理前と同じ無 色透明である。電解着色時間が長くなるにしたがって，析出物が バリヤー層から雁脱し始める時間が次第に不明瞭となる。すなわ ら, 電解着色時間が 10 分の皮膜の $j-t$ 曲線(2)に見られるよう に, 電流密度は時間の経過とともにゆるやかに低下し, 曲線 (1) に見られるような急激な低下は認められない。この原因は， Ni 析出物とバリヤー層を含めた周囲との密着珄が高まっているため と思われる。Ni 析出物がポアーから離脱を完了するのは, 電解 開始後約 360 秒である。このように $j-t$ 曲線からは, 少なくと も析出物のバリヤー層からの離脱終了点を求めることができる。

図 7 の硫酸スズ $(I)$ による電解着色皮膜の 2 本の $j-t$ 曲線は, 電解開始直後の電流密度がいずれも $100 \mathrm{~mA} \cdot \mathrm{cm}^{-2}$ 以上であるに むかかわらず，約 40 秒後には電流がほとんど流れなくなること を示している。電解開始直後の電流密度が高いことは, Sn 析出 物とバリヤー層との密着性がきわめてすぐれていることと, $\mathrm{Ni}$ 析出物のように析出物中に電気抵抗を增大させるような微細粒子 がなく, Sn 析出物が単結晶で形成されていることを裏付けるる のと考えられる。さらに $j-t$ 曲線がいずれも約 10〜 40 秒の間で 電流密度が急激に低下するが，この理由はバリヤー層の厚さがほ とんど変化しないことと, Sn 析出物の頂点面に新たな微細構造 が出現することを考え合わせると，Sn 析出物がアノード酸化さ れて表面層が不動態化したことを裏付けるものである。

この Sn 析出物の表面に出現する不動態層の組成は, 電子線回 折では非晶質を示している。もし仮に Sn 析出物の表面層に Sn$\mathrm{O}_{2}$ のような酸化物が生成したとすると, $\mathrm{SnO}_{2}$ は電気伝導性酸 化物であるため， $j-t$ 曲線の電流の急激な低下を説明できない。 しかし Sn 析出物の表面層が微細化して不動態化したと考える と，図 4 と $j-t$ 曲線に見られる電流の急激な低下を説明すること 
ができる。

図 7 の電解開始直後の電流密度の5ち曲線 (1)上り曲線 (2) の方が高くなっている原因は, Sn の皮膜への付き回り性がすぐ れていることによって, 電解時間が 5 分の皮膜は Sn 析出物がポ

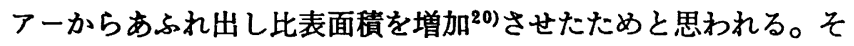
れゆえ Sn 析出物がポフーからあふれ出ず皮膜内にある場合に は, 硫酸ニッケルによる着色皮膜の場合と同様, 電解時間の長い 皮膜の方が電気抵抗が増加して電解開始直後の電流密度は低くな るものと推察される。

\section{5 結 論}

アルミニウムの電解着色皮膜は再アノード酸化時に色が淡色化 し，析出物の種類によって印加電圧または印加電圧と電解時間に よって色の镕調整が可能となり，着色制御できることが明らかと なった。また主として電子顕微鏡による観察と $j-t$ 特性から, 再 フノート酸化前後におけるポフー中の析出物とバリヤー層との微 細構造变化および析出物とハシャー層との密着性を追求して, 以 下の結論を得た。

電解着色処理時に析出物とバリヤー層との界面にこれらの間の 密着性を高めるコロイド状のアルミニウム化合物が生成するが その大きさは約 5〜7 nm 程度である。

20）佐治 孝，秋山明胤，安原清忠，金属表面技術，22，409 (1971).
析出物とバリヤー層との密着性は, 析出物の種類（金属塩の種 類)によって異なるだけでなくポアーによっても異なる。すなわ ち $\mathrm{Ni}$ 析出物においては, 再アノード酸化時の酸素ガスの発生が, 溶液と接する面だけでなく孔壁やバリヤー層との界面部分からも 起こるようである。したがって析出物のはく雒がバリヤー層や析 出物の途中で起こるため, 析出物はポフーから離脱する。このと き $\mathrm{Ni}$ 析出物の離脱はランダムに起こる。この原因は皮膜生成時 のバリヤー層の厚さのばらつさに起因するものと推察される。Sn 析出物では酸素ガスの発生が溶液と接する面でのみ起こるため, 析出物は上部がアノード酸化を受けて不動態層を形成しポアーか ら離脱しない。

析出物がポフーから離脱するかどらかは, 酸素ガスの発生简所 の違い,つまり析出物を形成する微細粒子の有無に関係すると思 われる。

$\mathrm{Ni}$ 析出物の離脱したあとのバリヤー層が増厚化によって強化 されるのに対し; Sn 析出物では表面層の不動態化によって強化 される。

本研究をまとめるにあたり，有益な助言をいただいた東京工業 大学の木村脩七教授および当研究所の牧島亮男主任研究官, そし てアルミニウムサブグループ研究会の委員各位には心から感謝致 します。

（1982 年 10 月，金属表面技術協会第 66 回学術講演大会(一 部)発表)

\title{
Variation of Microstructure and Color Control by Reanodizing of the Electrolytically Colored Films on Aluminum
}

\author{
Kenji Wada*, Yoshio Matsui, Yoshizo Sekikawa \\ and Takajiro Shimohira \\ National Institute for Research in Inorganic Materials; Namiki, \\ Sakura-mura, Niihari-gun, Ibaraki 305 Japan
}

This paper reports the results of the newly developed reanodizing method applying to the electrolytic colored films on aluminum. The purposes of the reanodizing method were to give various functions and more durability against the colored films. Porous anodic oxide films were formed in aqueous solution of sulfuric acid or phosphoric acid, and then coloring and reanodizing were performed on the films. As the results, the colors of the films, colorized by the deposition of nickel or tin, became lighter. The color of the films by the nickel deposition changed to colorless state which is generally obtained by the anodizing, while the color by tin slightly changed. The colors of these films were controlled by the reanodizing voltage and/or the electrolytic duration. Furthermore, variations of the microstructures in cross-section of the colored films were observed before and after reanodizing by a transmission electron microscope. From the observation by the transmission electron microscope and current density-reanodizing time curves, the following presumption was made: In the case of the nickel deposition, leaving of the nickel deposits from the pores by reanodizing causes the color change, while in the case of the tin deposition, the tin deposits in the pores were passivated by reanodizing and bring slight color change. Especially, the leaving of the nickel deposits from the pores seemed to depend on the presence of ultra fine particles in the deposits and on the uneven thickness of the anodized barrier layer. On the other hand, the durabilities of these colored films were found to be improved considerably by increasing the thickness of the barrier layer or by formation of the chemically stable passive state layer. 